\section{Ammonium Uptake Is the Main Driver of Rhizosphere pH in Southern Highbush Blueberry}

\author{
Christopher S. Imler, Camila I. Arzola, and Gerardo H. Nunez ${ }^{1}$ \\ Horticultural Sciences Department, University of Florida, P.O. Box 110690, \\ Gainesville, FL 32611
}

Additional index words. acidification, nitrogen, nitrate, Vaccinium, H+-ATPase

\begin{abstract}
Unlike most horticultural crops, blueberry (Vaccinium spp. section cyanococcus) prefers low-pH (4.2-5.5) soils. Other plants can acidify their rhizosphere to create a hospitable microenvironment. Southern highbush blueberry (SHB; Vaccinium corymbosum interspecific hybrids) plants do not acidify their rhizosphere in response to $\mathrm{Fe}$ deficiency, but other factors that affect rhizosphere $\mathrm{pH}$ have not been elucidated. We report results from two hydroponic experiments exploring $N$ uptake effects on the rhizosphere $\mathrm{pH}$ of 'Emerald' SHB. Ammonium $\left(\mathrm{NH}_{4}^{+}\right)$uptake led to rhizosphere acidification, whereas nitrate $\left(\mathrm{NO}_{3}^{-}\right)$uptake led to rhizosphere alkalization. When grown in a split-root hydroponic system, roots that took up $\mathrm{NH}_{4}^{+}$acidified the rhizosphere to a greater extent that roots not exposed to $\mathrm{NH}_{4}{ }^{+}$. Rhizosphere acidification was observed even in a nontreated control. These results suggest that $\mathrm{NH}_{4}{ }^{+}$uptake is the main driver of rhizosphere $\mathrm{pH}$ in SHB. $\mathrm{N}$ form effects suggest that fertilization with $\mathrm{NO}_{3}{ }^{-}$ might lead to undesirable rhizosphere alkalization.
\end{abstract}

Soil $\mathrm{pH}$ is a major factor mediating plant agricultural performance. Plants in family Ericaceae (i.e., acid-loving plants) thrive in acidic soils ( $\mathrm{pH} 4.2-5.5)$ where $\mathrm{NH}_{4}{ }^{+}$is the most abundant form of $\mathrm{N}$ (Marrs and Bannister, 1978). When acid-loving plants are grown in neutral or high-pH soils, they exhibit stress, nutritional deficiencies, stunted growth, and low survival (Finn et al., 1993; Marrs and Bannister, 1978; PayaMilans et al., 2017; Tsuda et al., 2014). Acidic soils are rare in agricultural and landscape settings. Thus, growers must find naturally acidic soils or rely on costly soil amendments (Almutairi et al., 2017; Williamson et al., 2015) or soilless substrates (Kingston et al., 2017) for the production of ericaceous crops, such as blueberries ( $\mathrm{Vacci}$ nium spp. section cyanococcus). Development of cultivars and practices that reduce dependence on these inputs requires a better understanding of the processes that affect rhizosphere $\mathrm{pH}$.

Some herbaceous and woody plants can acidify their rhizosphere (Gogorcena et al., 2001; Hawkins et al., 2008; Lei et al., 2015; Santi and Schmidt, 2009; Suzko et al., 2018; Valentinuzzi et al., 2015). Previous research suggests that plants acidify their rhizosphere to create more hospitable microenvironments for nutrient uptake and growth (Lei et al., 2015; Suzko et al., 2018). Plants acidify their

\footnotetext{
Received for publication 19 Nov. 2018. Accepted for publication $25 \mathrm{Feb} .2019$

This research was supported by the Thad Cochran Southern Horticultural Laboratory, U.S. Department of Agriculture Agricultural Research Service under NACA agreement no. 58-6062-5-005.

1Corresponding author. E-mail: g.nunez@ufl.edu.
}

rhizosphere by using plasma membranebound $\mathrm{H}^{+}$-ATPases (Santi and Schmidt, 2009) and/or by exuding organic acids (Marschner et al., 1987). Cells have a basal level of $\mathrm{H}^{+}$-ATPase activity, but several stimuli - such as cation uptake - can enhance this activity (Haynes, 1990). P and Fe deficiencies also increase $\mathrm{H}^{+}$-ATPase activity in some plants, as roots acidify the rhizosphere to solubilize these nutrients (Gogorcena et al., 2001; Jimenez et al., 2007; Lei et al., 2015).

$\mathrm{N}$ uptake is a major factor affecting rhizosphere $\mathrm{pH}$ because this element can be taken up as a cation and/or an anion. $\mathrm{NH}_{4}{ }^{+}$ uptake leads to rhizosphere acidification as cells extrude $\mathrm{H}^{+}$to maintain their electrical charge balance (Marschner et al., 1991). On the other hand, $\mathrm{NO}_{3}{ }^{-}$uptake leads to rhizosphere alkalization as the symport mechanism responsible for $\mathrm{NO}_{3}{ }^{-}$movement across the plasma membrane removes $\mathrm{H}^{+}$from the rhizosphere (Meharg and Blatt, 1995). Thus, the $\mathrm{N}$ form taken up by the plant can enhance or counteract $\mathrm{H}^{+}$-ATPase-mediated rhizosphere acidification.

SHB (Vaccinium corymbosum interspecific hybrids) is an economically important acid-loving plant (Perez and Ferreira, 2017). $\mathrm{NH}_{4}{ }^{+}$form (Merhaut and Darnell, 1995). Although SHB plants do not acidify their rhizosphere in response to $\mathrm{Fe}$ deficiency (Nunez et al., 2015), other factors that affect SHB rhizosphere $\mathrm{pH}$ are unknown. This research aims to quantify the effect of $\mathrm{NH}_{4}{ }^{+}$ uptake on SHB rhizosphere $\mathrm{pH}$ change. We hypothesized that $\mathrm{NH}_{4}^{+}$uptake is the main driver of rhizosphere acidification by SHB. We tested this hypothesis in two separate hydroponic experiments. SHB plants take up $\mathrm{N}$ preferentially in the
Plant material and acclimation period. One-year-old rooted cuttings of 'Emerald' SHB were washed clean of substrate using tap water. Cuttings were transplanted to a previously described hydroponic system (Poonnachit and Darnell, 2004) in which each plant was exposed to $2 \mathrm{~L}$ of constantly aerated nutrient solution. Plants were acclimated in a nutrient solution containing $0.5 \mathrm{~mm} \mathrm{KNO}_{3}, 0.5 \mathrm{~mm} \mathrm{~K}_{2} \mathrm{PO}_{4}, 1.0 \mathrm{~mm}$ $\mathrm{MgSO}_{4}, 0.5 \mathrm{~mm} \mathrm{CaCl}, 0.045 \mathrm{~mm} \mathrm{H}_{3} \mathrm{BO}_{3}$, $0.01 \mathrm{~mm} \mathrm{MnSO}_{4}, 0.01 \mathrm{~mm} \mathrm{ZnSO}_{4}$ with $0.3 \mu \mathrm{M} \mathrm{CuSO}, 0.2 \mu \mathrm{M} \mathrm{Na} \mathrm{NaO}_{4}$, and $45 \mu \mathrm{M}$ Fe provided as Sequestrene 330 (10\% iron(III)-diethylenetriamine pentaacetic acid) (Becker Underwood, Inc., Ames, IA). Nutrient solution was buffered to $\mathrm{pH} 5.5$ using $5.0 \mathrm{~mm}$ 2-(4-morpholino)-ethane sulfonic acid (MES). Nutrient solution $\mathrm{pH}$ was adjusted back to $\mathrm{pH} 5.5$ using $1 \mathrm{M} \mathrm{HCl}$ or $1 \mathrm{M}$ $\mathrm{KOH}$ as needed, three times each week. Fresh nutrient solution was provided every $7 \mathrm{~d}$ to maintain nutrient concentrations. Debris, algae, and detached roots were removed from the reservoir to minimize impact on solution $\mathrm{pH}$. Acclimation lasted $21 \mathrm{~d}$ in both experiments. Plant fresh weight $(\mathrm{FW})$ was measured nondestructively at the end of acclimation.

All experiments were carried out in a temperature-controlled greenhouse set to maintain air temperatures between 15.6 and $26.7{ }^{\circ} \mathrm{C}$. Natural light was supplemented by metal halide lamps with a photosynthetic photon flux density output of $367 \mathrm{nmol} \cdot \mathrm{m}^{-2} \cdot \mathrm{s}^{-1}$ for $14 \mathrm{~h}$ every day.

Expt. 1: Nitrogen form effect. After acclimation, one half of the plants were transferred to a nutrient solution in which $5 \mathrm{~mm}$ $\mathrm{NO}_{3}{ }^{-}$(delivered as $\mathrm{KNO}_{3}$ ) was the only form of $\mathrm{N}$. The other half of the plants received a nutrient solution in which $5 \mathrm{~mm} \mathrm{NH}_{4}^{+}$[delivered as $\left.\left(\mathrm{NH}_{4}\right)_{2} \mathrm{SO}_{4}\right]$ was the only form of $\mathrm{N}$. Additional salts were not added to compensate for $\mathrm{K}^{+}$and $\mathrm{SO}_{4}^{-}$concentrations. Considering that the magnitude of $\mathrm{N}$ uptake is much greater than $\mathrm{K}^{+}$and $\mathrm{SO}_{4}^{-}$uptake (Havlin et al., 2013), it is reasonable to assume that most changes in rhizosphere $\mathrm{pH}$ were the result of $\mathrm{N}$ form as opposed to these counterions. In addition, $\mathrm{KNO}_{3}$ and $\left(\mathrm{NH}_{4}\right)_{2}$ $\mathrm{SO}_{4}$ have been used as blueberry fertilizers in previous scientific studies with SHB (Nunez et al., 2015). Nutrient solutions were adjusted to $\mathrm{pH} 5.5$ during nutrient solution preparation, but they did not contain any $\mathrm{pH}$ buffer. All other nutrient concentrations were the same as during the acclimation period. $\mathrm{Nu}$ trient solution in reservoirs with no plants was used as the control for each treatment. Nutrient solution $\mathrm{pH}, \mathrm{N}$ uptake, and leaf chlorophyll content were measured periodically. The treatment period lasted $35 \mathrm{~d}$.

This experiment followed a completely randomized design with one variable $(\mathrm{N}$ form) and two treatments $\left(\mathrm{NH}_{4}{ }^{+}\right.$and $\left.\mathrm{NO}_{3}{ }^{-}\right)$. Individual plants were the experimental unit. There were four single-plant replications per treatment. All data except for rhizosphere $\mathrm{pH}$ 
were analyzed using one-way analysis of variance (ANOVA) in $\mathrm{R}$ version 3.5.1 ( $\mathrm{R}$ Core Team, 2017). Rhizosphere $\mathrm{pH}$ data were analyzed using a linear mixed model (see section Rhizosphere $\mathrm{pH}$ measurement).

Expt. 2: Ammonium uptake effect. After acclimation, plants were transplanted to a split-root hydroponic system. Plants were held upright using garden stakes and Velcro straps (Supplemental Fig. 1). Root systems were separated into two parts of similar volume. Each half of the root system was placed in a different 1.5 -L reservoir (termed reservoir A and reservoir B). In reservoir A, all plants were exposed to a complete, buffered nutrient solution that contained $5 \mathrm{~mm}$ $\mathrm{NH}_{4}^{+}$. $\mathrm{NH}_{4}^{+}$concentration treatments were delivered in reservoir B. Seven plants were exposed to a nutrient solution containing $5 \mathrm{mM} \mathrm{NH}_{4}^{+}$in reservoir $\mathrm{B}$, whereas seven different plants received a nutrient solution without $\mathrm{N}$ in reservoir $\mathrm{B}$. $\mathrm{NH}_{4}^{+}$was delivered as $\left(\mathrm{NH}_{4}\right)_{2} \mathrm{SO}_{4}$ in all solutions. Nutrient solutions were adjusted to $\mathrm{pH} 5.5$ during nutrient solution preparation. Solutions in reservoir A were buffered with 5.0 mM MES. Solutions in reservoir B were not buffered to track $\mathrm{pH}$ change. All other nutrient concentrations were the same as during the acclimation period. In summary, treatments were (reservoir $\mathrm{A}$ /reservoir B) $\mathrm{NH}_{4}^{+} / \mathrm{NH}_{4}^{+}$and $\mathrm{NH}_{4}{ }^{+}$/ $0 \mathrm{~N}$. Reservoirs with no plants were used as controls for each treatment. Nutrient solution $\mathrm{pH}, \mathrm{N}$ uptake, and leaf chlorophyll content were measured periodically. Root vitality was measured $30 \mathrm{~d}$ after transplant to the split-root system. The treatment period lasted $35 \mathrm{~d}$. At the end of this period, plants were harvested destructively to measure plant and organ dry weight and tissue $\mathrm{N}$ content.

This experiment followed a completely randomized design with one variable $\left(\mathrm{NH}_{4}{ }^{+}\right.$ concentration in reservoir $\mathrm{B})$ and two treatments $\left(0 \mathrm{~mm} \mathrm{NH}_{4}^{+}\right.$and $\left.5 \mathrm{~mm} \mathrm{NH}_{4}^{+}\right)$. Individual plants were the experimental unit. There were seven single-plant replications per treatment. All data except for rhizosphere $\mathrm{pH}$ were analyzed using one-way ANOVA in $\mathrm{R}$ version 3.5.1 ( $\mathrm{R}$ Core Team, 2017). When appropriate, reservoir A and reservoir B were compared via paired one-tail $t$ tests $(\alpha=$ $0.05)$. Rhizosphere $\mathrm{pH}$ data were analyzed using a linear mixed model (see section Rhizosphere $\mathrm{pH}$ measurement).

Rhizosphere $\mathrm{pH}$ measurement. Nutrient solution $\mathrm{pH}$ was measured three times per week during the treatment period in both experiments using a standardized portable pH meter (Accumet AP110; Fisher Scientific, Hampton, NH). Solution crosscontamination and disturbance of fine roots was avoided during $\mathrm{pH}$ measurement. Rhizosphere $\mathrm{pH}$ for a single treatment on a single day was compared with controls using onesample single-tail $t$ tests $(\alpha=0.05)$ performed in $\mathrm{R}$ version 3.5.1 ( $\mathrm{R}$ Core Team, 2017). Treatments were compared through linear mixed-effect analysis in $\mathrm{R}$ version 3.5.1 using package lme4 (Bates et al., 2015). Midweek $\mathrm{pH}$ data were used. Treatment, treatment duration, and their interaction were designated as fixed effects; repeated measures per subject and week were designated as random sources of error. Statistical significance was determined by likelihood ratio tests comparing the full model against a model without the effect being investigated. Linear regression slopes are provided only as a reference.

Nitrogen uptake. Nutrient solution volume was measured at the end of each week. About $20 \mathrm{~mL}$ solution was collected in scintillation vials from each reservoir. Samples were filtered through a fine-wire mesh to remove debris, acidified with 1 drop $1 \mathrm{~N} \mathrm{HCl}$, and stored frozen at $-20{ }^{\circ} \mathrm{C}$. Samples were submitted for analysis at an institutional laboratory (University of Florida IFAS Analytical Research Laboratory, Gainesville, FL), where $\mathrm{NO}_{3}{ }^{-}$and $\mathrm{NH}_{4}{ }^{+}$concentrations were measured by automated colorimetry according to Environmental Protection Agency protocols 353.2 and 351.2, respectively (U.S. Environmental Protection Agency, 1993a, 1993b). Both $\mathrm{NO}_{3}^{-}$and $\mathrm{NH}_{4}{ }^{+}$concentrations were measured in all nutrient solution samples. Nutrient solution volumes and concentrations were used to determine $\mathrm{N}$ content after $7 \mathrm{~d}$ of plant exposure. $\mathrm{N}$ removal from the nutrient solution was computed by subtracting $\mathrm{N}$ content after $7 \mathrm{~d}$ from the $\mathrm{N}$ content of fresh nutrient solution. $\mathrm{N}$ uptake was normalized according to whole-plant FW. Nitrification rates were estimated from the $\mathrm{NO}_{3}{ }^{-}$concentration at day 7 in control reservoirs that received $\mathrm{NH}_{4}{ }^{+}-$ containing nutrient solution.

Chlorophyll status and $N$ content. Plants were harvested destructively after 5 weeks of treatment. Canes, leaves, and roots from each reservoir were dried to a constant weight and ground until they passed through a \#20 mesh screen. $\mathrm{N}$ content in these samples was measured through combustion-thermal conductivity at a commercial laboratory (Waters Agricultural Laboratories, Camila, GA) according to Association of Analytical Communities protocol 2.4.02 (Association of Analytical Communities, 2012). Chlorophyll status was measured nondestructively using a leaf greenness SPAD 502 meter (Konika Minolta, Osaka, Japan). Unitless measurements were made on three positions on the youngest fully expanded leaf of each plant at the end of the acclimation period and during week 3 of treatment.

Root viability. Relative electrolyte leakage (REL) was used to assess root viability per McKay and White (1997). Root tissue samples $(\approx 250 \mathrm{mg})$ were collected from each reservoir. Root samples contained a thirdorder root and all the attached lower order roots. This sampling method has been used previously to study SHB roots (Nunez et al., 2015). Roots were blotted dry, submerged in $16 \mathrm{~mL}$ deionized $\mathrm{H}_{2} \mathrm{O}$, and incubated for $24 \mathrm{~h}$ under continuous shaking at $\approx 60 \mathrm{rpm}$. Electrical conductivity was measured immediately after incubation and after autoclaving for $30 \mathrm{~min}$ at $121{ }^{\circ} \mathrm{C}$ using a standardized conductivity meter (Accumet XL30, Fisher
Scientific). Deionized water incubated with no roots was used as an assay control.

\section{Results and Discussion}

Nitrogen form effect on rhizosphere $\mathrm{pH}$. In our experiment, cumulative $\mathrm{NH}_{4}^{+}$uptake by 'Emerald' SHB was significantly greater than $\mathrm{NO}_{3}{ }^{-}$uptake $(5.66 \mathrm{mg} \mathrm{N} / \mathrm{g} \mathrm{FW}$ vs. $4.11 \mathrm{mg} \mathrm{N} / \mathrm{g} \mathrm{FW}, P=0.03)$. Nitrification in the nutrient solution was negligible (average, $0.50 \mu \mathrm{mol} \mathrm{NO}{ }_{3}^{-} /$reservoir/d). Although it is possible that the low replication number in this experiment affected the analyses, these trends are consistent with previous studies in which SHB and other acid-loving plants exhibited a preference for $\mathrm{NH}_{4}^{+}$uptake over $\mathrm{NO}_{3}{ }^{-}$uptake (Merhaut and Darnell, 1995; Poonnachit and Darnell, 2004; Townsend, 1966). Low $\mathrm{NO}_{3}^{-}$uptake is also consistent with the significantly lower chlorophyll status observed in $\mathrm{NO}_{3}{ }^{-}$-grown plants compared with $\mathrm{NH}_{4}^{+}$-grown ones during week 3 of treatment (36.28 SPAD vs. 59.78 SPAD, $P=0.02)$. FW and dry weight (DW) data were lost as a result of human error, but observations indicated that biomass accumulation mirrored $\mathrm{N}$ uptake and chlorophyll status trends.

$\mathrm{NH}_{4}{ }^{+}$-grown 'Emerald' SHB plants acidified their rhizosphere consistently and significantly within $3 \mathrm{~d}$ of each solution change (Fig. $1, P \leq 0.0001$ in all cases). $\mathrm{NO}_{3}{ }^{-}$-grown plants alkalized their nutrient solution starting on day 5 of the experiment $(P \leq 0.01$ in all cases). $\mathrm{N}$ form-dependent rhizosphere acidification and alkalization is consistent with previous reports in blueberry (Merhaut and Darnell, 1995; Nunez et al., 2015), and other woody (Gogorcena et al., 2001; Hawkins et al., 2008; Marschner et al., 1991; Suzko et al., 2018; Valentinuzzi et al., 2015) and herbaceous (Lei et al., 2015; Santi and Schmidt, 2009) plants. When analyzed through a linear mixed-effect model, the interaction between $\mathrm{N}$ source and treatment duration affected rhizosphere $\mathrm{pH}$ significantly $\left(\chi^{2}=10.18\right.$, df $\left.=1, P \leq 0.01\right)$. Midweek rhizosphere $\mathrm{pH}$ of $\mathrm{NH}_{4}^{+}$-grown plants was nearly constant (linear regression slope $=-0.01$ ), whereas midweek rhizosphere $\mathrm{pH}$ of $\mathrm{NO}_{3}{ }^{-}$-grown plants increased over time (linear regression slope $=0.15$ ). $\mathrm{N}$ source also affected rhizosphere $\mathrm{pH}\left(\chi^{2}=\right.$ 48.64, $\mathrm{df}=1, P \leq 0.001) . \mathrm{NO}_{3}{ }^{-}$uptake raised rhizosphere $\mathrm{pH}$ by an average of 3.52 units compared with $\mathrm{NH}_{4}^{+}$uptake (Supplemental Fig. 2). Treatment duration did not affect rhizosphere $\mathrm{pH}$ significantly $\left(\chi^{2}=3.59, \mathrm{df}=\right.$ $1, P=0.06$ ).

Although $\mathrm{NH}_{4}{ }^{+}$-containing fertilizers are the basis for blueberry nutrition, $\mathrm{NO}_{3}{ }^{-}$is not absent from the blueberry rhizosphere. Fertilizers used for conventional (Kennedy, 2011; Liu et al., 2012; Smith and Harris, 2017) and organic (Larco et al., 2013) blueberry production can contain mixes of $\mathrm{NH}_{4}^{+}$ and $\mathrm{NO}_{3}{ }^{-}$. Also, nitric acid-which dissociates into $\mathrm{NO}_{3}{ }^{-}$- can be used to acidify blueberry fertigation (Gallegos-Cedillo et al., 2018). In addition, blueberry soils can 


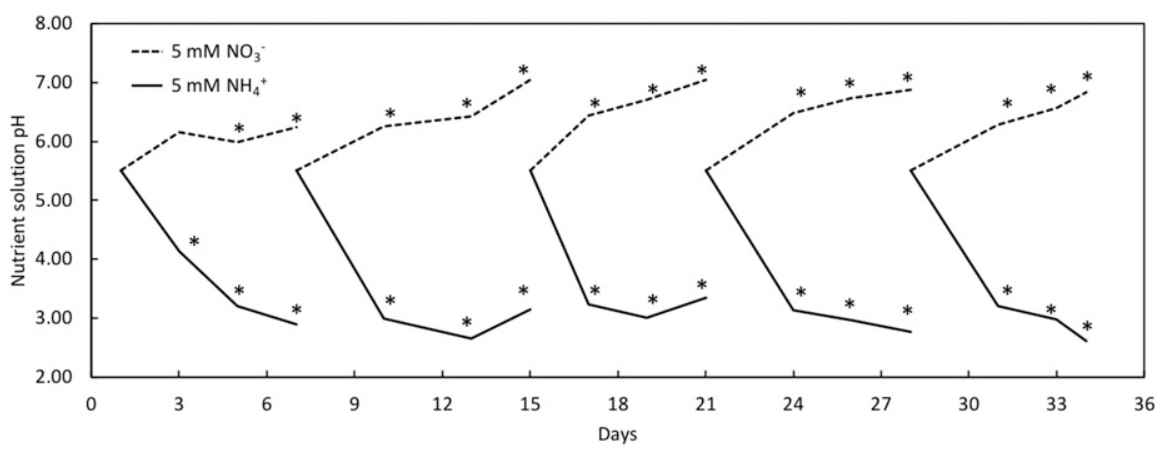

Fig. 1. Rhizosphere $\mathrm{pH}$ of 'Emerald' southern highbush blueberry plants grown in a complete nutrient solution containing $5 \mathrm{mM} \mathrm{NO}_{3}^{-}$(dashed lines) or $5 \mathrm{mM} \mathrm{NH}_{4}^{+}$(solid lines). Fresh nutrient solution at $\mathrm{pH}$ 5.5 was delivered every week. Asterisks indicate significant differences from nutrient solution $\mathrm{pH}$ in reservoirs with no plants at $P \leq 0.05$.

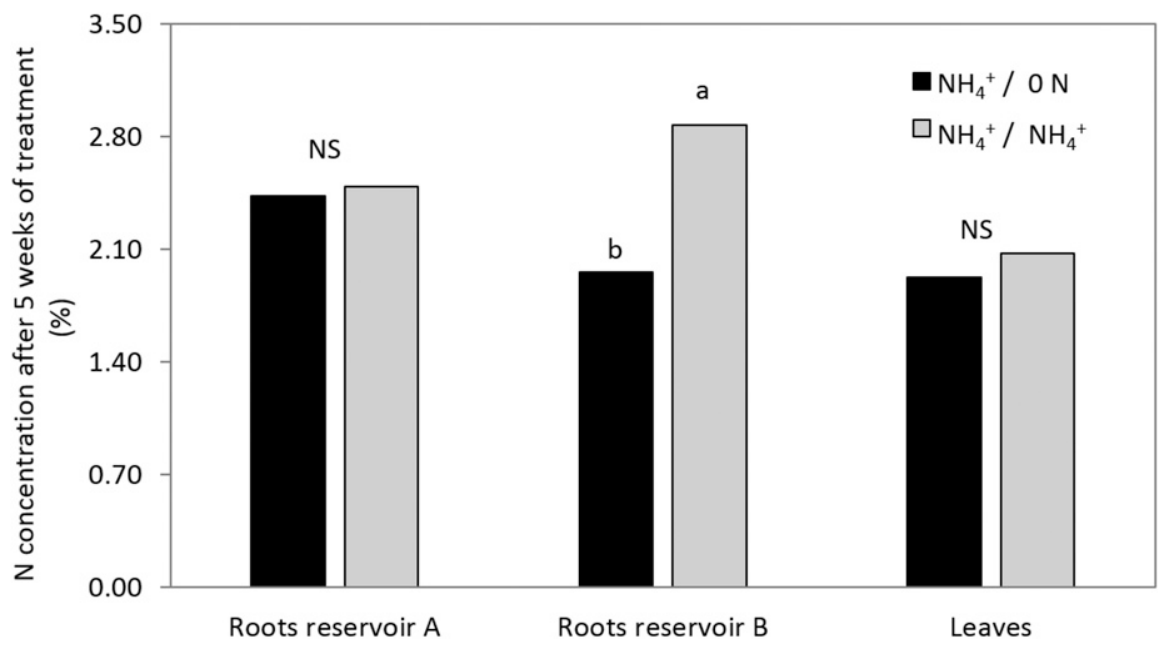

Fig. 2. N concentration in roots and leaves of hydroponically grown 'Emerald' southern highbush blueberry as determined by combustion-thermal conductivity. Plants were grown in a split-root hydroponic system in which reservoir A contained a complete nutrient solution buffered to $\mathrm{pH} 5.5$, and reservoir B contained a nonbuffered nutrient solution containing $5 \mathrm{mM} \mathrm{NH}_{4}{ }^{+}$(treatment $\mathrm{NH}_{4}^{+} / \mathrm{NH}_{4}{ }^{+}$) or no $\mathrm{N}$ (treatment $\left.\mathrm{NH}_{4}{ }^{+} / 0 \mathrm{~N}\right)$. Different letters indicate significant differences between treatments $(P \leq$ $0.05)$. Ns $=$ not significant.

have high nitrification rates (Hanson et al., 2002). Our results suggest that using $\mathrm{NO}_{3}{ }^{-}$for blueberry fertilization might lead to rhizosphere alkalization. In blueberry, high rhizosphere $\mathrm{pH}$ can lead to nutrient deficiencies, stunted growth, and low survival (Finn et al., 1993; Tsuda et al., 2014). Thus, $\mathrm{NO}_{3}{ }^{-}$use would exacerbate the need for soil amendments and soilless substrates for blueberry cultivation. Further research is necessary to establish the extent to which $\mathrm{NH}_{4}{ }^{+}: \mathrm{NO}_{3}{ }^{-}$ combinations affect rhizosphere $\mathrm{pH}$ under field conditions.

The observed rhizosphere acidification in $\mathrm{NH}_{4}{ }^{+}$-grown 'Emerald' SHB plants represents a conundrum, because it is not possible to determine whether these plants acidify their rhizosphere independently from the effect of $\mathrm{NH}_{4}^{+}$uptake. Previously, rhizosphere acidification capacity has been used as a proxy to identify genotypes with broad soil adaptation (Suzko et al., 2018) or superior nutrient uptake capacity (Lei et al., 2015). Thus, determining whether SHB is
N/g FW vs. $2.73 \mathrm{mg} \mathrm{N} / \mathrm{g} \mathrm{FW}, P=0.04)$. N uptake from reservoir A was not significantly different between treatments (average = $2.46 \mathrm{mg} \mathrm{N} / \mathrm{g} \mathrm{FW}, P=0.10$ ). All N uptake in treatment $\mathrm{NH}_{4}{ }^{+} / 0 \mathrm{~N}$ was from reservoir $\mathrm{A}$, because reservoir $\mathrm{B}$ did not contain $\mathrm{N}$. These results are consistent with previous studies in which plants that were exposed to low nutrient concentrations in one half of their root systems took up less nutrients overall (Ma and Rengel, 2008; Shen et al., 2005).

Nutrient solution $\mathrm{NH}_{4}{ }^{+}$concentration affected root $\mathrm{N}$ concentration. Roots in reservoir $\mathrm{B}$ in treatment $\mathrm{NH}_{4}^{+} / 0 \mathrm{~N}$ exhibited significantly lower $\mathrm{N}$ concentrations than roots in reservoir B in treatment $\mathrm{NH}_{4}{ }^{+} / \mathrm{NH}_{4}{ }^{+}$ $(P<0.001)$. Roots in reservoir B in treatment $\mathrm{NH}_{4}^{+} / \mathrm{NH}_{4}^{+}$exhibited significantly greater $\mathrm{N}$ concentrations than roots in reservoir $\mathrm{A}$ in all treatments $(P<0.01)$, suggesting there was greater $\mathrm{NH}_{4}{ }^{+}$uptake from nutrient solutions that were not buffered. Contrasting $\mathrm{N}$ uptake and root $\mathrm{N}$ concentration in reservoir $\mathrm{B}$ did not affect whole-plant $\mathrm{N}$ status. Treatments did not affect plant DW (average $=29.38 \mathrm{~g}$, $P=0.42$ ), root $\mathrm{N}$ concentrations in reservoir A $(P=0.76)$, or leaf $\mathrm{N}$ concentration $(P=0.31$, Fig. 2). All leaf $\mathrm{N}$ concentrations were within previously established sufficiency ranges for blueberry (Smith and Harris, 2017; Strik and Vance, 2015). In addition, leaf chlorophyll status did not change between acclimation and treatment periods (49.1 SPAD vs. 52.4 SPAD, $P=0.21$ ), and it was not significantly different between $\mathrm{NH}_{4}^{+} / \mathrm{NH}_{4}{ }^{+}$and $\mathrm{NH}_{4}{ }^{+} / 0 \mathrm{~N}$ plants during the treatment period $(55.0$ SPAD vs. 49.9 SPAD, $P=0.11$ ). These results suggest that overall plant $\mathrm{N}$ status was unaffected by the treatments in the 5week treatment period used in this experiment. It is likely that prolonged cultivation under these conditions could lead to $\mathrm{N}$ deficient plants in treatment $\mathrm{NH}_{4}^{+} / 0 \mathrm{~N}$.

Roots in reservoir B of all treatments acidified their rhizosphere consistently and significantly starting $2 \mathrm{~d}$ after each solution change (Fig. 3, $P \leq 0.0009$ in all cases). The magnitude of rhizosphere acidification by roots exposed to $\mathrm{NH}_{4}^{+}$in their nutrient solution was comparable between Expts. 1 and 2, and it is consistent with previous reports (Marschner et al., 1991). When analyzed through a linear mixed-effect model, the interaction between $\mathrm{NH}_{4}^{+}$concentration in reservoir $\mathrm{B}$ and treatment duration significantly affected rhizosphere $\mathrm{pH}\left(\chi^{2}=8.36\right.$, $\mathrm{df}=1, P<0.01)$. Midweek nutrient solution $\mathrm{pH}$ remained relatively constant in treatment $\mathrm{NH}_{4}{ }^{+} / \mathrm{NH}_{4}{ }^{+}$(linear regression slope $=$ -0.17) (Supplemental Fig. 3), suggesting that rhizosphere acidification in these plants responded to a constant stimulus, such as $\mathrm{NH}_{4}^{+}$uptake. In contrast, midweek nutrient solution $\mathrm{pH}$ decreased over time in treatment $\mathrm{NH}_{4}+/ 0 \mathrm{~N}$ (linear regression slope $=-0.31$ ), suggesting that rhizosphere acidification in these plants increased in response to changing conditions. It is possible that diminishing root $\mathrm{N}$ concentrations in reservoir $\mathrm{B}$ of treatment $\mathrm{NH}_{4}{ }^{+} / 0 \mathrm{~N}$ increased the rhizosphere acidification capacity in these roots (local 


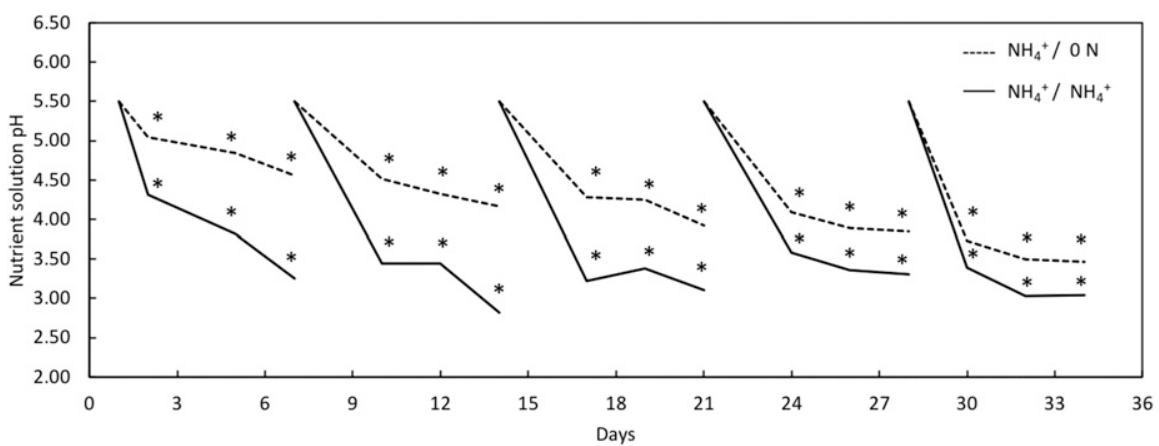

Fig. 3. Rhizosphere $\mathrm{pH}$ of 'Emerald' southern highbush blueberry plants grown in a split-root hydroponic system in which reservoir A contained a complete nutrient solution buffered to $\mathrm{pH} 5.5$, and reservoir B contained a nonbuffered nutrient solution containing $5 \mathrm{mM} \mathrm{NH}_{4}{ }^{+}$(treatment $\mathrm{NH}_{4}{ }^{+} / \mathrm{NH}_{4}{ }^{+}$, solid lines) or no $\mathrm{N}$ (treatment $\mathrm{NH}_{4}{ }^{+} / 0 \mathrm{~N}$, dashed lines). Fresh nutrient solution at $\mathrm{pH} 5.5$ was delivered every week. Asterisks indicate significant differences from nutrient solution $\mathrm{pH}$ in bottles with no plants at $P \leq$ 0.05 .

response). In addition, it is possible that the entire root system in treatment $\mathrm{NH}_{4}^{+} / 0 \mathrm{~N}$ responded to $\mathrm{NH}_{4}^{+}$uptake from reservoir $\mathrm{A}$ (systemic response). Additional research is necessary to elucidate whether local or systemic responses are involved in this apparent acclimation.

$\mathrm{NH}_{4}{ }^{+}$concentration in reservoir $\mathrm{B}\left(\chi^{2}=\right.$ 7.45, $\mathrm{df}=1, P<0.006)$ and treatment duration $\left(\chi^{2}=12.63, \mathrm{df}=1, P<0.0004\right)$ also affected rhizosphere $\mathrm{pH}$ significantly. Ammonium uptake decreased rhizosphere $\mathrm{pH}$ by an average of 0.75 units beyond basal rhizosphere acidification (Supplemental Fig. 3). These results are consistent with an increase in $\mathrm{H}^{+}$-ATPase activity as a consequence of cation uptake. Molecular and genetic evidence for this phenomenon are available for model species [see Hachiya and Sakakibara (2017) for review], but not for blueberry. Root organic acid exudation increases when $\mathrm{P}$ and micronutrients are scarcely bioavailable (Marschner et al., 1987). Considering P and micronutrients were equally abundant in both treatments, it is unlikely that organic acid exudation was involved in rhizosphere $\mathrm{pH}$ change in our experiment.

Previously, lack of rhizosphere acidification in Vaccinium spp. was ascribed to relaxed selection in the acidic soils where these species evolved (Nunez et al., 2015). Our results contradict this notion, as 'Emerald' SHB plants are, in fact, capable of acidifying their rhizosphere. In the future, additional genotypes and related taxa should be tested to determine whether there is variation in this trait among cultivated and wild Vaccinium spp.

Other woody and herbaceous species are capable of acidifying their rhizosphere even when they take up $\mathrm{NO}_{3}^{-}$(Gogorcena et al., 2001; Hawkins et al., 2008; Santi and Schmidt, 2009), suggesting their $\mathrm{H}^{+}$extrusion rates (from $\mathrm{H}+$-ATPase activity or organic acid exudation) are greater than $\mathrm{H}^{+}$ influx rates through the $\mathrm{H}^{+} / \mathrm{NO}_{3}^{-}$symport. In our experiment, 'Emerald' SHB plants were capable of acidifying their rhizosphere when grown with $\mathrm{NH}_{4}{ }^{+}$or without $\mathrm{N}$, but not when grown with $\mathrm{NO}_{3}{ }^{-}$. These results suggest that 'Emerald' $\mathrm{SHB} \mathrm{H}^{+}$extrusion rates are less than $\mathrm{H}^{+}$influx rates caused by $\mathrm{NO}_{3}{ }^{-}$ uptake. Considering that blueberry plants are exposed to $\mathrm{NH}_{4}{ }^{+}$and $\mathrm{NO}_{3}{ }^{-}$under typical field conditions (Hanson et al., 2002), further research is necessary to determine whether they can create an acidic microenvironment around their roots in agricultural settings.

In conclusion, $\mathrm{N}$ uptake is the main driver of rhizosphere $\mathrm{pH}$ in 'Emerald' $\mathrm{SHB}$. $\mathrm{NH}_{4}{ }^{+}$ uptake, in particular, appears to be essential for maintaining low rhizosphere $\mathrm{pH}$. These findings advance our understanding of rhizosphere chemistry in acid-loving plants and provide a baseline for testing $\mathrm{NH}_{4}{ }^{+}: \mathrm{NO}_{3}{ }^{-}$ mixes and other Vaccinium spp. in the future.

\section{Literature Cited}

Almutairi, K.F., R.M.A. Machado, D.R. Bryla, and B.C. Strik. 2017. Chemigation with micronized sulfur rapidly reduces soil $\mathrm{pH}$ in a new planting of northern highbush blueberry. HortScience 52:1413-1418.

Association of Analytical Communities. 2012. AOAC protocol 2.4.02. In: Official methods of analysis of AOAC International. 19th ed. AOAC International, Rockville, MD.

Bates, D., M. Maechler, B. Bolker, and S. Walker. 2015. Fitting linear mixed-effects models using lme4. J. Stat. Softw. 67:1-48.

Finn, C.E., J.J. Luby, C.J. Rosen, and P.D. Ascher 1993. Blueberry germplasm screening at several soil $\mathrm{pH}$ regimes: I. Plant survival and growth. J. Amer. Soc. Hort. Sci. 118:377-382.

Gallardo, R.K., Q. Zhang, M. Dosset, J.J. Polashok, C. Rodriguez-Saona, N. Vorsa, P.P. Edger, H. Ashrafi, E. Babiker, C.E. Finn, and M. Iorizzo, 2018. Breeding trait priorities of the blueberry industry in the United States and Canada. HortScience 53:1021-1028.

Gallegos-Cedillo, V.M., J.E. Alvaro, T. Capatos, T.L. Hachmann, G. Carrasco, and M. Urrestarazu. 2018. Effect of $\mathrm{pH}$ and silicon in fertigation solution on vegetative growth of blueberry plants in organic agriculture. HortScience 53:1423-1428.

Gogorcena, Y., N. Molias, A. Larbi, J. Abadia, and A. Abadia. 2001. Characterization of the responses of cork oak (Quercus suber) to iron deficiency. Tree Physiol. 21:1335-1340.

Hachiya, T. and H. Sakakibara. 2017. Interactions between nitrate and ammonium in their uptake, allocation, assimilation, and signaling in plants. J. Expt. Bot. 68:2501-2512.

Hanson, E.J., P.A. Throop, S. Serce, J. Ravenscroft, and E.A. Paul. 2002. Comparison of nitrification rates in blueberry and forest soils. J. Amer. Soc. Hort. Sci. 127:136-142.

Havlin, J.L., S.L. Tisdale, W.R. Nelson, and J.D. Beaton. 2013. Soil fertility and fertilizers. Pearson, London, UK.

Hawkins, B.J., H. Boukcim, and C. Plassard. 2008. A comparison of ammonium, nitrate and proton net fluxes along seedling roots of Douglas-fir and lodgepole pine grown and measured with different inorganic nitrogen sources. Plant Cell Environ. 31:278-287.

Haynes, R.J. 1990. Active ion uptake and maintenance of cation-anion balance: A critical examination of their role in regulating rhizosphere pH. Plant Soil 126:247-264.

Jimenez, S., Y. Gogorcena, C. Hevin, A.D. Rombola, and N. Ollat. 2007. Nitrogen nutrition influences some biochemical responses to iron deficiency in tolerant and sensitive genotypes of Vitis. Plant Soil 290:343-355.

Kennedy, S. 2011. Impact of nitrogen forms and ratios and substrate $\mathrm{pH}$ on blueberry root and shoot development. Tennessee State Univ., UMI no. 1502972, MS thesis.

Kingston, P. H.S., C.F. Skagel, and D.R. Bryla 2017. Suitability of sphagnum moss, coir, and douglas fir bark as soilless substrates for container production of highbush blueberry. HortScience 52:1692-1699.

Larco, H., B.C. Strick, D.R. Bryla, and D.M. Sullivan. 2013. Mulch and fertilizer management practices for organic production of highbush blueberry: II. Impact on plant and soil nutrients during establishment. HortScience 48:1484-1495.

Lei, K.J., J.Y. Xie, Y.Y. Zhu, C.P. Song, and G.Y An. 2015. Screening and analysis of rhizosphere acidification deficiency mutants in Arabidopsis thaliana under low phosphorus. Soil Sci. Plant Nutr. 61:493-500.

Liu, G., J. Williamson, G. England, and A. Whidden. 2012. How to calculate fertigation injection rates for commercial blueberry production. UF IFAS Extension document HS1197. Univ. of Florida, Gainesville, FL.

Ma, Q. and Z. Rengel. 2018. Phosphorus acquisition and wheat growth are influenced by shoot phosphorus status and soil phosphorus distribution in a split-root system. J. Plant Nutr. Soil Sci. 171:266-271.

Marrs, R.H. and P. Bannister. 1978. Response of several members of the Ericaceae to soils of contrasting $\mathrm{pH}$ and base-status. J. Ecol. 66:829834.

Marschner, H., M. Häussling, and G. Ekhard. 1991. Ammonium and nitrate uptake rates and rhizosphere $\mathrm{pH}$ in non-mycorrhizal roots of norway spruce [Picea abies (L.) Karst.]. Trees (Berl.) $5: 14-21$

Marschner, H., V. Romheld, and L. Cakmak. 1987. Root-induced changes of nutrient availability in the rhizosphere. J. Plant Nutr. 10:11751184.

McKay, H.M. and I.M.S. White. 1997. Fine root electrolyte leakage and moisture content: Indices of sitka spruce and douglas-fir seedling performance after desiccation. New For. 13:139162.

Meharg, A.A. and M.R. Blatt. 1995. $\mathrm{NO}_{3}{ }^{-}$transport across the plasma membrane of Arabidopsis thaliana root hairs: Kinetic control by $\mathrm{pH}$ and membrane voltage. J. Membr. Biol. 145:49-66.

Merhaut, D.J. and R.L. Darnell. 1995. Ammonium and nitrate accumulation in containerized 
southern highbush blueberry plants. HortScience 30:1378-1381.

Nunez, G.H., J.W. Olmstead, and R.L. Darnell. 2015. Rhizosphere acidification is not part of the strategy I iron deficiency response of Vaccinium arboreum and the southern highbush blueberry. HortScience 50:10641069.

Paya-Milans, M., G.H. Nunez, J.W. Olmstead, T.A. Rinehart, and M. Staton. 2017. Regulation of gene expression in roots of the $\mathrm{pH}$-sensitive Vaccinium corymbosum and the $\mathrm{pH}$-tolerant Vaccinium arboreum in response to near neutral $\mathrm{pH}$ stress using RNA-Seq. BMC Genomics 18:580.

Perez, A. and G. Ferreira. 2017. USDA Economic Research Service fruit and tree nut yearbook. 22 June 2017. <https://usda.library.cornell.edu/ concern/publications/7h149p84n?locale=en $>$.

Poonnachit, U. and R.L. Darnell. 2004. Effect of ammonium and nitrate on ferric chelate reductase and nitrate reductase in Vaccinium species. Ann. Bot. 93:399-405.

R Core Team. 2017. R: A language and environment for statistical computing. R Foundation for Statistical Computing, Vienna, Austria. 10 Aug. 2017. <https://www.R-project.org/>.
Santi, S. and W. Schmidt. 2009. Dissecting iron deficiency-induced proton extrusion in Arabidopsis roots. New Phytol. 183:1072-1084.

Shen, J., H. Li, and G. Neumann. 2005. Nutrient uptake, cluster root formation and exudation of protons and citrate in Lupinus albus as affected by localized supply of phosphorus in a splitroot system. Plant Sci. 168:292-298.

Smith, E.D. and G. Harris. 2017. Plant nitrogen status of southern highbush blueberry ( $\mathrm{Vacci}$ nium corymbosum L. interspecific hybrid) grown in pine bark amended soils with varying rates of nitrates. Commun. Soil Sci. Plant Anal. 48:878-885.

Strik, B.C. and A.J. Vance. 2015. Seasonal variation in leaf nutrient concentration of northern highbush blueberry cultivars grown in conventional and organic production systems. HortScience 5:1453-1466.

Suzko, A.Q., T.A. Rinehart, J.M. Bradeen, and S.C. Hokanson. 2018. An evaluation of two seedling phenotyping protocols to assess $\mathrm{pH}$ adaptability in deciduous azalea (Rhododendron sect. Pentanthera G. Don). HortScience 53:268-274.

Townsend, L.R. 1966. Effect of nitrate and ammonium nitrogen on the growth of the lowbush blueberry. Can. J. Plant Sci. 46:209-210.
Tsuda, H., H. Kinitake, Y. Aoki, A. Oyama, T Tetsumura, H. Komatsu, and K. Yoshioka. 2014. Efficient in vitro screening for higher soil $\mathrm{pH}$ adaptability of intersectional hybrids in blueberry. HortScience 49:141-144.

U.S. Environmental Protection Agency. 1993a. Determination of nitrate-nitrite nitrogen by automated colorimetry, p. 353.2-1-353.2-13. Office of Research and Development U.S. Environmental Protection Agency, Cincinnati, $\mathrm{OH}$.

U.S. Environmental Protection Agency. 1993b. Determination of total Kjeldahl nitrogen by semi-automated colorimetry, p. 351.2-1351.2-13. Office of Research and Development U.S. Environmental Protection Agency, Cincinnati, $\mathrm{OH}$.

Valentinuzzi, F., Y. Pii, G. Vigani, M. Lehmann, S. Cesco, and T. Mimmo. 2015. Phosphorus and iron deficiencies induce a metabolic reprogramming and affect the exudation traits of the woody plant Fragaria $\times$ ananassa. J. Expt. Bot. 66:6483-6495.

Williamson, J.G., J.W. Olmstead, and P.M. Lyrene. 2015. Florida's commercial blueberry industry. Univ. of Florida, Horticultural Sci. Dept., Gainesville, FL: IFAS Ext. 


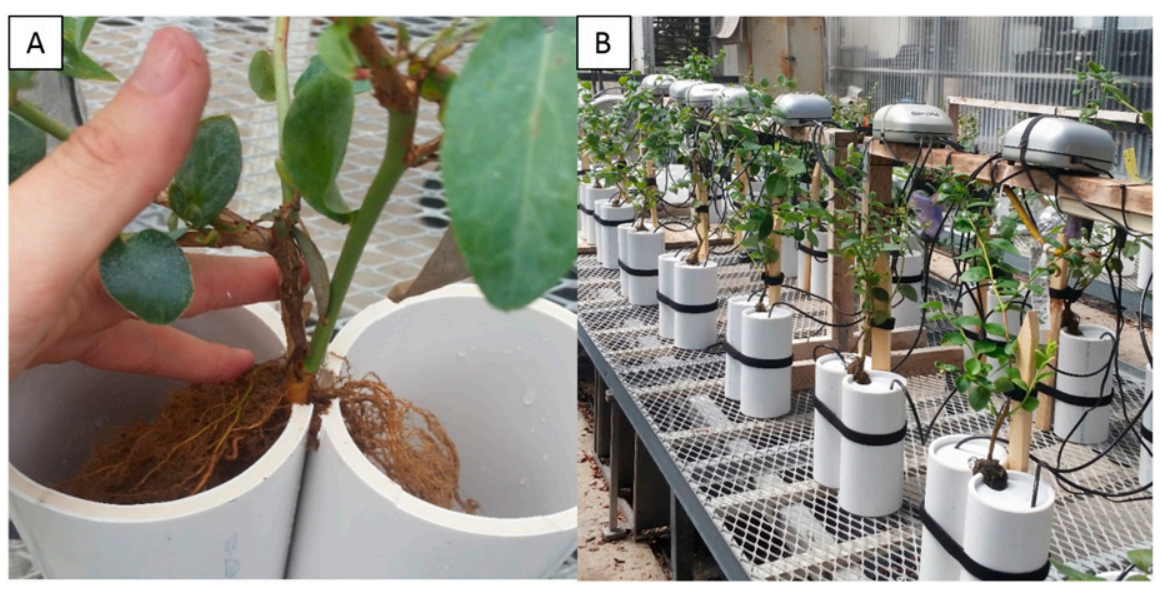

Supplemental Fig. 1. Split-root hydroponic system used to grow 'Emerald' southern highbush blueberry. (A) Root systems were split in two halves. Each half was placed inside a 1.5-L reservoir. (B) Reservoirs were held together by Velcro straps; plants were held upright using garden stakes.

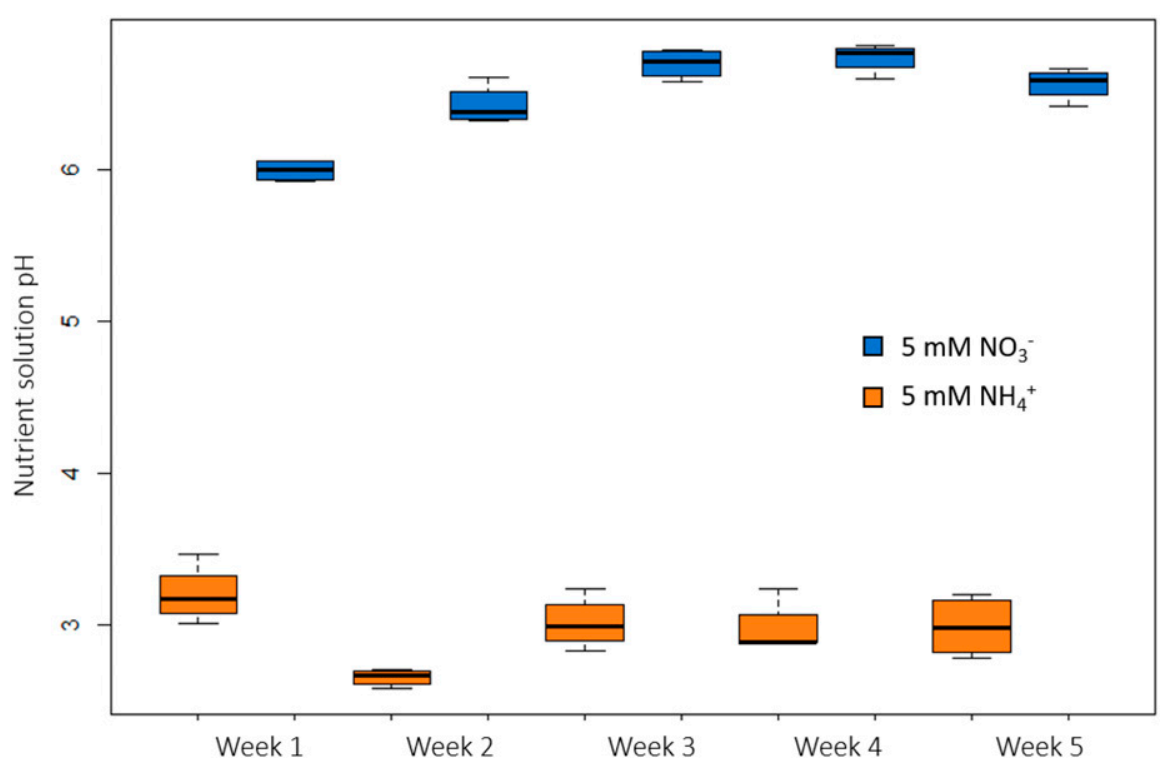

Supplemental Fig. 2. Midweek nutrient solution pH of 'Emerald' southern highbush blueberry plants grown in a complete nutrient solution containing $5 \mathrm{mM} \mathrm{NO}_{3}^{-}$(blue) or $5 \mathrm{mM} \mathrm{NH}_{4}^{+}$(orange). Data shown were analyzed using a linear mixed-effect model. 


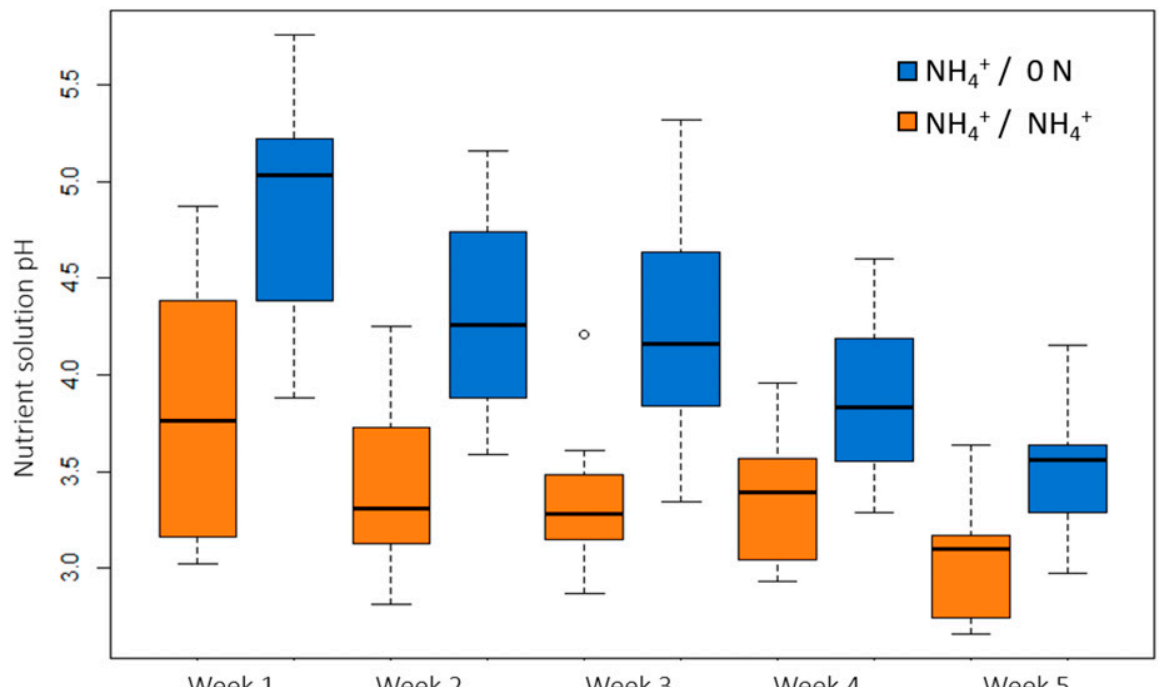

Supplemental Fig. 3. Midweek nutrient solution pH of 'Emerald' southern highbush blueberry plants grown in a split-root hydroponic system. Reservoir A contained a complete nutrient solution buffered to $\mathrm{pH}$ 5.5; reservoir B contained a nonbuffered nutrient solution containing $5 \mathrm{mM} \mathrm{NH}_{4}^{+}$(treatment $\mathrm{NH}_{4}{ }^{+} / \mathrm{NH}_{4}{ }^{+}$, orange) or no $\mathrm{N}$ (treatment $\mathrm{NH}_{4}{ }^{+} / 0 \mathrm{~N}$, blue). Data shown were analyzed using a linear mixed-effect model. 